\title{
Pelatihan Manajemen Organisasi dan Kepemimpinan di Kelurahan Batulayar, Desa Batulayar, Lombok Barat
}

\begin{abstract}
Abdurrahman ${ }^{1}$, Isra' Dewi Kuntary Ibrahim², Rini Anggriani ${ }^{3}$, Mochamad Najib Rodhi ${ }^{4}$, Irwan Cahyadi $^{5}$, Raden Bagus Faisal Irany Sidharta ${ }^{6}$, M. Thonthowi Jauhari $^{7}$, Puspita Dewi ${ }^{8}$, Rangga Mulya Jati ${ }^{9}$, Gustu Yudi Artha ${ }^{10}$, Mimi Fadila ${ }^{11}$

Abdurrahman@universitasbumigora.ac.id ${ }^{1}$, israibrahim@universitasbumigora.ac.id ${ }^{2}$, rinianggriani@universitasbumigora.ac.id ${ }^{3}$, m.najib@universitasbumigora.ac.id ${ }^{4}$, irwancahyadi@universitasbumigora.ac.id ${ }^{5}$, raden.sidharta@universitasbumigora.ac.id ${ }^{6}$, thonthowi jauhari@universitasbumigora.ac.id ${ }^{7}$, puspitadewi@universitasbumigora.ac.id ${ }^{8}$, ranggamulyajati71@gmail.com ${ }^{9}$ gustuyudi29@gmail.com ${ }^{10}$, mimifadila62722@gmail.com ${ }^{11}$
\end{abstract}

1,2,3,4,5,6,7,8,9,10,11 Universitas Bumigora

\author{
Article History: \\ Received: \\ Revised: \\ Accepted: \\ Keywords: Organizational \\ Management, Leadership, \\ Organization
}

\begin{abstract}
This training aims to provide organizational and leadership knowledge in running and managing an organization through the application of appropriate organizational management and leadership based on the characteristics of an organization. Organizational management is useful to determine the success and sustainable development in the midst of the times in the current era of globalization, an organization must have a good system. A good organization should have members who have adequate management knowledge in running an organization so that the vision and mission can be achieved according to the goals and or ideals of the organization and stakeholders. The results of this training activity showed that the level of understanding of the participants had increased, as evidenced by the results of the discussion of the case as well as problem solving and finding solutions presented by the participants in accordance with the material presented previously. The importance of this training for the organization is because the existence of this training will provide added value for the management and members of the organization so that they can run their organizations effectively and efficiently so as to achieve the stated organizational goals.
\end{abstract}

\section{Pendahuluan}

Dalam sebuah organisasi terdapat suatu sistem yang bernama Manajemen Organisasi, sistem ini diperlukan untuk kelancaran operasional suatu organisasi dalam rangka mewujudkan visi dan misi. Sebuah organisasi akan survive dan berkembang jika pengelolaannya dilakukan dengan baik dan benar. Pentingnya pengelolaan organisasi / 


\section{ADMA}

Durnal Pengabdian dan Pemberdayaan Masyarakat
Vol.1, No.1, June 2020, pp. 1-10

Doi: $x x x x x x x x$

manajemen organisasi sangat diperlukan guna meningkatkan kualitas sumber daya yang dimiliki untuk mencapai tujuan yang telah ditetapkan secara efektif dan efisien. Manajemen merupakan ilmu dan seni dalam mengatur, mengendalikan, mengkomunikasikan dan memanfaatkan semua sumber daya yang ada dalam organisasi dengan memanfaatkan fungsi-fungsi manajemen (Planning, Organizing, Actuating, Controlling) agar organisasi dapat mencapai tujuan secara efektif dan efesien (Kristiawan, M., Safitri, D., \& Lestari, 2017).

Marno, (2008) menyebutkan bahwa manajemen adalah kemampuan dan keterampilan untuk memperoleh sesuatu hasil dalam rangka pencapaian tujuan melalui kegiatan-kegiatan orang lain. Dalam perspektif lebih luas, manajemen adalah suatu proses pengaturan dan pemanfaatan sumber daya yang dimiliki organisasi melalui kerjasama para anggota untuk mencapai tujuan organisasi secara efektif dan efisien. Berarti manajemen merupakan perilaku anggota dalam suatu organisasi untuk mencapai tujuannya. Dengan kata lain, organisasi adalah wadah bagi operasionalisasi manajemen (Syafaruddin, 2015).

Menurut Masruri, (2018) dalam ilmu manajemen terdapat 5 teori fungsi utama manajemen yaitu:

1. Planning (Perencanaan)

Proses inilah yang digunakan untuk menentukan tujuan dari suatu organisasi dalam bentuk visi dan misi baik jangka panjang juga jangka pendek. Selain itu, strategi yang harus dipakai juga sudah harus ditentukan dari awal. Supaya, dalam pelaksanaannya akan mendapat kemudahan dan kelancara dalam mencapai tujuan organisasi.

2. Organizing (Mengorganisasi)

Fungsi ini digunakan untuk mengorganisasi atau mengatur orang-orang yang ada dalam suatu organisasi tersebut. Supaya, mereka dapat menjalankan peran juga fungsi mereka masing masing secara jelas dan efektif.

3. Staffing (Penempatan)

Hampir sama dengan dengan organizing, Staffing ini lebih meluas cakupannya. Kalau organizing condong memanajemeni SDM sedangkan staffing lebih ke sumber daya secara lebih meluas/umum. Contoh, peralatan dan inventaris yang dimiliki suatu kelompok atau organisasi.

4. Coordinating (Mengkoordinasi)

Coordinating berfungsi untuk meningkatkan efisensi dan efektifitas kinerja suatu organisasi, menjadikan suasana dalam organisasi kerja menjadi dinamis dan aktif,serta sehat juga nyaman dll. Fungsi ini diemban oleh manajer, jadi manajer memiliki fungsi penting dan utama untuk mengkoordinasi bawahannya agar performanya dapat meningkatkan.

5. Controlling (Mengontrol)

Pada fungsi ini terdapat hal-hal penting, semisal evaluasi dan juga pembuatan kebijakan baru.

Dari penjabaran dan uraian diatas maka inti dari manajemen adalah mengatur orang lain supaya tujuan organisasi dapat dicapai secara efektif dan efisisen. Untuk mencapai tujuan suatu organisasi maka diperlukan sosok pemimpin yang mampu mempengaruhi anggota atau bawahan dalam mewujudkan cita-cita organisasi dan para stakeholders. 
Adapun yang dimaksud dengan kepemimpinan adalah suatu perilaku dengan tujuan tertentu untuk mempengaruhi aktivitas para anggota kelompok untuk mencapai tujuan bersama yang dirancang untuk memberikan manfaat individu dan organisasi, sehingga dalam suatu organisasi kepemimpinan merupakan faktor yang sangat penting dalam menentukan pencapaian tujuan yang telah ditetapkan oleh organisasi (Rivai, 2013). Sedangkan menurut Hasibuan, (2016) menyatakan bahwa Gaya Kepemimpinan adalah cara seorang pemimpin mempengaruhi perilaku bawahan yang bertujuan untuk mendorong gairah kerja, kepuasan kerjadan produktivitas karyawan yang tinggi, agar dapat mencapai tujuan organisasi yang maksimal.

Kepemimpinan yang diterapkan harus mampu mengimplementasikan berbagai program yang direncanakan. Seorang pemimpin harus mempunyai kemampuan membangun team kerja yang solid. Namun disisi yang lain apabila seorang pemimpin gagal atau keliru dalam mengambil keputusan maka dapat berdampak pada menurunnya performa organisasi hingga berujung pada bubarnya organisasi tersebut. Dampak lain dari kegagalan kepemimpinan dalam mengelola organisasi adalah bergesernya nilai-nilai kepercayaan individu anggota organisasi dan masyarakat. Sementara salah satu aspek penting dalam membangun organisasi adalah soliditas, kepercayaan antar sesama anggota serta hubungan dengan masyarakat menjadi faktor kunci suatu organisasi agar tetap survive dan dapat diterima dalam masyarakat. Untuk mengatasi persoalan tersebut penting untuk meningkatkan pengetahuan anggota organisasi akan manajemen organisasi dan pola kepemimpinan yang baik dalam menjalankan organisasi tersebut.

Salah satu tujuan dari pengabdian ini adalah untuk memberikan pengetahuan keorganisasian dalam menjalankan suatu organisasi melalui manajemen organisasi dan kepemimpinan pada anggota organisasi di Kelurahan Batulayar. Adapun permasalahannya adalah masih banyak anggota organisasi terutama organisasi yang ada di Kelurahan Batulayar belum memiliki pengetahuan akan manajemen organisasi dan kepemimpinan yang baik dalam menjalankan organisasinya. Oleh karena itu, perlu adanya pelatihan manajemen organisasi dan kepemimpinan menggunakan metode komunikasi kelompok agar dapat lebih di pahami.

Kelurahan Batulayar merupakan salah satu kelurahan yang berada dekat pesisir pantai yang berlokasi di Lombok barat, daerah ini memiliki potensi sumber daya alam yang begitu berlimpah. Dari sisi SDM, masyarakat di daerah ini mayoritas bermata pencaharian sebagai nelayan dan sector informal lainnya. Namun demikian, potensi yang ada belum sepenuhnya dikelola dengan optimal. Banyak organisasi atau komunitas remaja terbentuk untuk mewujudkan kelurahan Batulayar agar terus maju dan berkembang guna mengelola potensi sumberdaya yang dimiliki. Namun dari hasil survey awal yang dilakukan oleh para komunitas perguruan tinggi menemukan bahwa pengetahuan dan pemahaman pengelolaan manajemen dan kepemimpinan yang baik dan benar para anggota organisasi masih sangat minim bahkan masih sangat rendah. Berdasarkan hal inilah komunitas perguruan tinggi merasa perlu untuk berkontribusi memberikan pelatihan pengelolaan manajamen dan kepemimpinan pada anggota organisasi di Batulayar.

Setiap organisasi memerlukan pengelolaan manajemen dan kepemimpinan yang baik dan benar, sehingga pengelolaan dan manajemen organisasi layak untuk dipelajari. Beberapa manfaat mempelajari dan memperluas pengetahuan tentang beberapa teori, konsep, 
proses, teknik, dan mekanisme manajemen yaitu dapat mengembangkan keterampilan dan menerapkan konsep manajemen pada situasi tertentu, membantu dalam pengambilan keputusan dan membantu meningkatkan kesejahteraan hidup serta menghapus keterbelakangan manajerial. Manajemen yang baik dibutuhkan untuk semua tipe kegiatan dalam organisasi, baik organisasi besar maupun kecil.

\section{Metode Pelaksanaan Pengabdian}

Permasalahan yang terjadi disetiap organisasi adalah masih kurang memahami pengetahuan akan manajemen dan kepemimpinan, sehingga perlu dilakukan pelatihan manajemen organisasi dan kepemimpinan menggunakan metode komunikasi kelompok. Komunikasi kelompok merupakan komunikasi yang berlangsung antara seseorang komunikator kepada sekelompok orang yang jumlahnya lebih dari dua orang. Karena apabila komunikasi seseorang atau dua orang itu termasuk komunikasi antar pribadi (Effendy, 2003). Metode ini dilakukan melalui ceramah sesuai dengan materi manajemen organisasi dan kepemimpinan dilanjutkan dengan diskusi dan tanya jawab selanjutnya diberikan pelatihan dalam melakukan pengelolaan organisasi, pengendalian internal organisasi dan teknik kepemimpinan. Kegiatan ini dilaksanakan dalam bentuk talkshow.

\section{a. Jadwal Pelaksanaan}

Berikut jadwal pelaksanaan kegiatan pengabdian:

1) Lokasi Pelaksanaan

Kegiatan pengabdian ini dilaksanakan di Kelurahan Batulayar, Desa Batu layar. Lokasi pelatihan di Taman Batu layar yang beralamat di Jl. Batulayar,Lombok Barat.

2) Pembicara Jajaran Dosen Manajemen (sebagai pembicara) dan Mahasiswa (sebagai pendamping).

1. Rini Anggriani, SE., MM (Dosen)

2. Isra' Dewi Kuntary Ibrahim, SE., MM (Dosen)

3. Abdurrahman, SE., MM (Dosen)

4. M. Najib Rodhi, SE., MM (Dosen)

5. Irwan Cahyadi, SE., MM (Dosen)

6. Raden Bagus Faisal Irani Sidharta, SE., MM (Dosen)

7. Rangga Mulyajati (Mahasiswa)

8. Gustu Yudi Artha (Mahasiswa)

9. Saddam Aminullah Amri (Mahasiswa)

10. Ni Kadek Ira Kusumawardani (Mahasiswi)

11. Ahmad Zunnurraini (Mahasiswa)

12. Izwandi (Mahasiswa)

13. Merry (Mahasiswi)

14. Mimi Fadila (Mahasiswi)

15. Nuratul Aini Afriani (Mahasiswi)

16. M. Rizki Ramdan (Mahasiswa)

17. Ayu Fitriani Pratiwi (Mahasiswi)

18. Janicha Yuanda Tania (Mahasiswi)

19. Bakti Suminarianto (Mahasiswa)

20. Arip Wicaksono (Mahasiswa) 
3) Waktu Pelaksanaan

Kegiatan pelatihan dilaksanakan selama 2 (dua) hari, terhitung dari tanggal 27 dan 28

Desember 2019. Berikut ini susunan rundown kegiatan pelatihan:

Tabel 1. Rundown Kegiatan Pelatihan

\begin{tabular}{|c|c|c|c|}
\hline Waktu & Kegiatan & Pencapaian & Sasaran \\
\hline \multirow[b]{2}{*}{$\begin{array}{l}\text { Hari } \\
\text { Pertama } \\
\text { tanggal } 27 \\
\text { Desember } \\
2019\end{array}$} & $\begin{array}{l}\text { Diskusi awal terkait } \\
\text { kendala dan masalah } \\
\text { yang dihadapi oleh } \\
\text { anggota organisasi }\end{array}$ & $\begin{array}{l}\text { Peserta dapat } \\
\text { mengidentifikasi masalah } \\
\text { yang dihadapi. }\end{array}$ & $\begin{array}{l}\text { Seluruh peserta dapat } \\
\text { menyelesaikan Masalah yang } \\
\text { dihadapi dan mulai tau langkah apa } \\
\text { yang harus dilakukan. }\end{array}$ \\
\hline & $\begin{array}{l}\text { Selanjutnya penyampaian } \\
\text { materi terkait pengelolaan } \\
\text { manajemen organisasi }\end{array}$ & $\begin{array}{l}\text { Peserta dapat memahami } \\
\text { bagaimana mengelola } \\
\text { organisasi dan } \\
\text { menjalankan fungsi } \\
\text { manajemen guna } \\
\text { mencapai visi, misi dan } \\
\text { tujuan organisasi yang } \\
\text { telah ditentukan. }\end{array}$ & $\begin{array}{l}\text { - Seluruh peserta dapat } \\
\text { mengetahui bagaimana } \\
\text { mengelola organisasi yang } \\
\text { efektif guna mencapai tujuan } \\
\text { organisasi. } \\
\text { - Seluruh peserta mampu } \\
\text { mengambil keputusan secara } \\
\text { tepat dalam menjalankan } \\
\text { fungsi manajemen sesuai } \\
\text { dengan masalah yang } \\
\text { dihadapi. }\end{array}$ \\
\hline \multirow[b]{2}{*}{$\begin{array}{c}\text { Hari Kedua } \\
\text { tanggal } 28 \\
\text { Desember } \\
2019\end{array}$} & $\begin{array}{l}\text { Penyampaian materi } \\
\text { kepemimpinan }\end{array}$ & $\begin{array}{l}\text { Peserta dapat memahami } \\
\text { bagaimana seharusnya } \\
\text { memimpin dan tipe } \\
\text { kepemimpinan yang ideal } \\
\text { dalam mengelola } \\
\text { organisasi menjadi lebih } \\
\text { baik }\end{array}$ & $\begin{array}{l}\text { Meningkatkan pengetahuan dan } \\
\text { keterampilan anggota organisasi } \\
\text { terkait pola atau tehnik } \\
\text { kepemimpinan dalam mengelola } \\
\text { organisasi yang baik dan benar. }\end{array}$ \\
\hline & 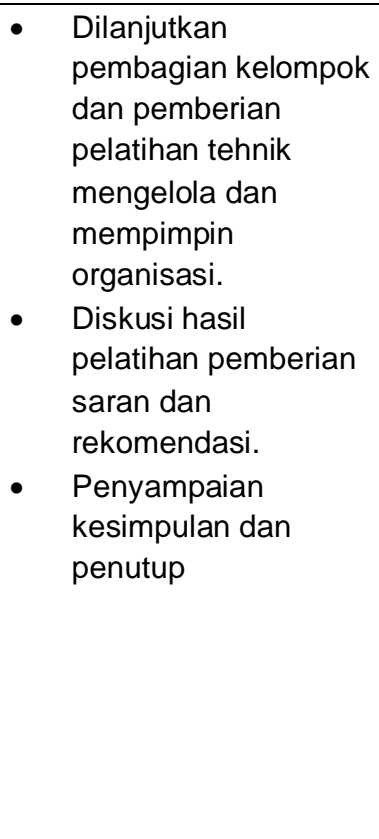 & $\begin{array}{l}\text { Peserta menceritakan } \\
\text { pengalaman dalam } \\
\text { mengelola organisasi dan } \\
\text { kendala yang dihadapi }\end{array}$ & $\begin{array}{l}\text { - Seluruh peserta mempunyai } \\
\text { pengetahuan bagaimana } \\
\text { mengelola setiap } \\
\text { permasalahan yang ada dan } \\
\text { solusi arternatif pemecahan } \\
\text { masalah yang dihadapi. } \\
\text { Meningkatkan pemahaman } \\
\text { anggota tentang bagaimana } \\
\text { seorang pemimpin harus } \\
\text { bersikap dalam menyikapi } \\
\text { setiap permasalahan dan } \\
\text { perubahan yang terjadi. } \\
\text { Seluruh peserta dapat } \\
\text { menjalankan tata kelola } \\
\text { organisasinya dengan baik } \\
\text { dan benar. } \\
\text { Kegiatan pelatihan ini dapat } \\
\text { berguna bagi kemajuan tata } \\
\text { kelola organisasi jangka } \\
\text { panjang. }\end{array}$ \\
\hline
\end{tabular}




\section{b. Tahapan Pelaksanaan}

Adapun tahapan dalam pelaksanaan kegiatan pelatihan ini adalah sebagai berikut:

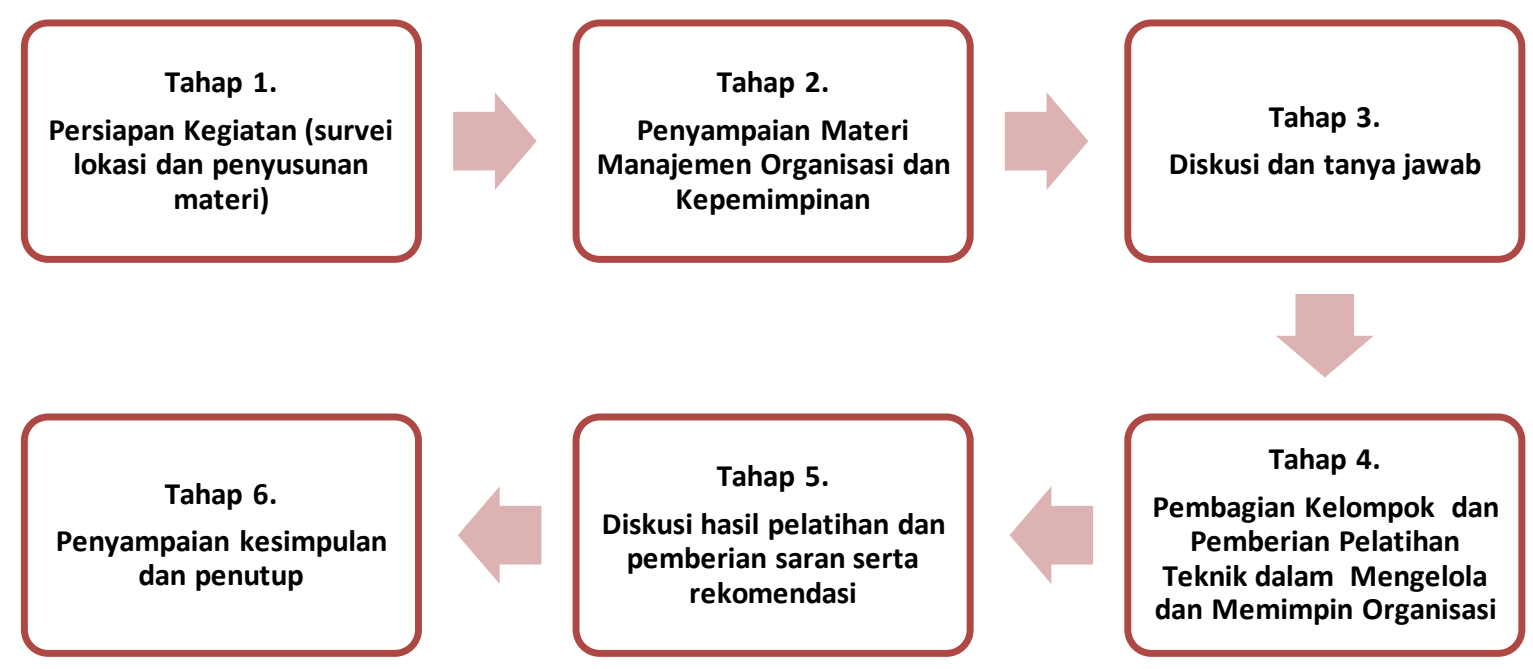

\section{Gambar 1. Tahapan Pelaksanaan Kegiatan Pelatihan}

\section{Hasil}

Kegiatan pelatihan manajemen organisasi dalam meningkatkan pengetahuan keorganisasian serta kepemimpinan bagi peserta pelatihan telah dilaksanakan pada tanggal 27 dan 28 Desember 2019 bertempat di Taman Batulayar, Lombok Barat. Kegiatan pelatihan berjalan dengan lancar dan sesuai dengan rencana. Kegiatan ini dihadiri oleh 60 orang dari beberapa kalangan organisasi di Batu layar, Peserta pelatihan terlihat antusias terhadap kegiatan ini khususnya materi-materi yang disampaikan. Peserta pelatihan juga mengikuti acara ini selama dua hari dari awal sampai dengan selesai.

Pada hari pertama disampaikan mengenai materi manajemen organisasi. Materi yang disampaikan dari penjelasan fungsi dari manajemen, mulai dari perencanaan, pengorganisasian, pengarahan dan pengontrolan dalam sebuah organisasi yang benar. Semua peserta sangat antusias dengan materi tersebut, terbukti dengan banyaknya peserta yang bertanya pada saat sesi tanya jawab berlangsung. Semua pertanyaan dibahas sampai selesai dan dapat dimengerti oleh peserta.

Pada hari selanjutnya atau hari kedua, materi yang disampaikan mengenai materi kepemimpinan. Materi ini membahas tentang bagaimana menjadi seorang pemimpin yang mampu membawa sebuah organisasi mencapai tujuan dengan pengambilan keputusan yang cepat dan tepat. Pada sesi Tanya jawab materi tersebut banyak peserta yang menceritakan pengalamannya di organisasinya dalam melakukan pengendalian internal dan pengambilan keputusan. Banyak yang semakin paham bahwa pengendalian internal dan pengambilan keputusan yang tepat dan cepat dalam organisasi sangatlah penting guna kelangsungan organisasi. Berikut dokumentasi kegiatan 


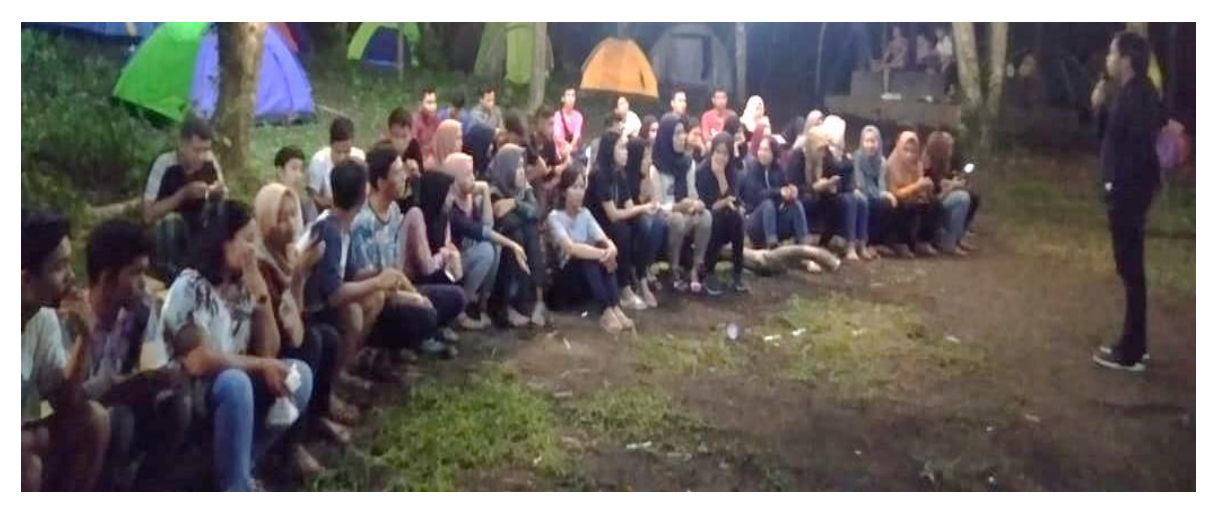

Gambar 1. Penyampaian Materi Kepemimpinan

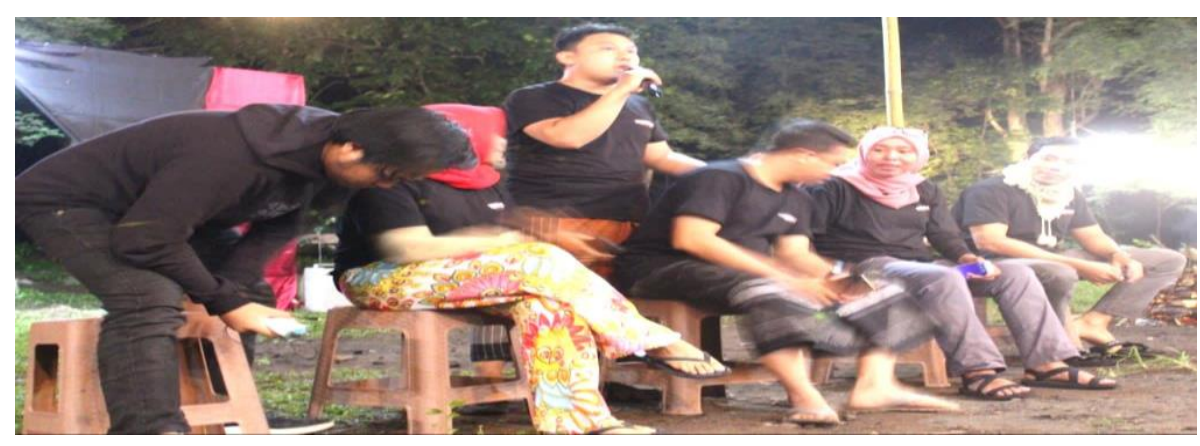

Gambar 2. Brainstorming

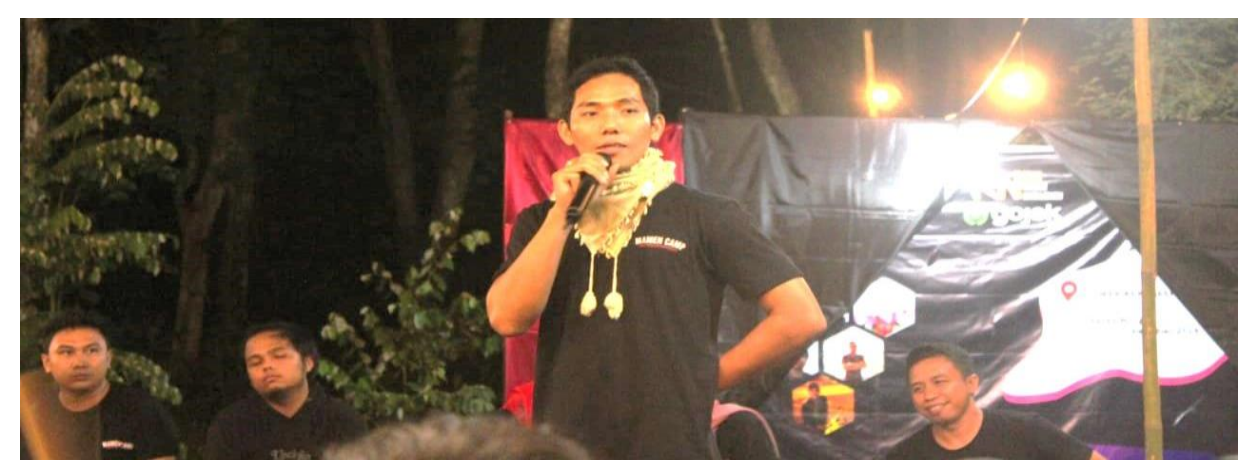

Gambar 3. Penyampaian Materi Manajemen Organisasi

\section{Diskusi}

Semua materi telah disampaikan dan diskusi melalui Tanya jawab selanjutkan dibentuk group discussion untuk membahas kasus-kasus organisasi yang telah disiapkan oleh pembicara serta terdapat beberapa masalah yang harus diselesaikan yang tentunya berkaitan dengan materi yang telah disampaikan. Group discussion ini dianggap menjadi salah satu cara yang efektif dalam suatu kegiatan atau proses pembelajaran. Berdasarkan hasil penelitian Dewi (2019) yang menyatakan bahwa group discussion dapat membantu dan memotivasi partisipan atau siswa untuk membangun kognitif skill mereka. Semua group berdiskusi, lalu menyusun perencanaan, pengorganisasian, pengarahan dan pengontrolan di lingkup group masing-masing dengan kasus permasalahan manajemen organisasi yang berbeda-beda,mencari solusi atas masalah tersebut serta memilih teknik kepemimpinan 


\section{ADMA}

seperti apa agar kasus tersebut terselesaikan dengan baik. Setelah kasus diselesaikan maka dilakukan diskusi keseluruhan dan dibahas satu per satu kasus yang ada serta dilakukan evaluasi, pemberian saran dan rekomendasi terhadap kasus tersebut.

Berdasarkan hasil kegiatan pelatihan ini tingkat pemahaman peserta mengalami peningkatan, terbukti dari hasil diskusi kasus serta pemecahan masalah dan pencarian solusi yang dipaparkan oleh peserta sudah sesuai dengan materi yang disampaikan sebelumnya. Hasil diskusi dan materi yang disampaikan besarharapan diterapkan oleh peserta pada organisasi tempat mereka bernaung sehingga organisasi tersebut lebih terstruktur dan tertata agar dapat mencapai tujuan organisasi denganbaik.

\section{Kesimpulan}

Adapun kesimpulan dari hasil kegiatan pengabdian masyarakat kepada pengurus organisasi di Batulayar adalah bahwa ada peningkatan pemahaman, pengetahuan dan keterampilan anggota organisasi terkait bagaimana mengelola manajemen organisasi dan kepemimpinan yang baik dan benar dalam mengambil keputusan dan alternative solusi dari setiap permasalahan yang dihadapi. Hal ini ditujukan dengan meningkatnya antusias dan partisipasi anggota dalam bertanya selama diskusi berlangsung. Banyak anggota organisasi menyampaikan kendala yang mereka hadapi dalam mengelola organisasi. Sehingga setelah dilakukanya pelatihan ini anggota organisasi merasa perlu untuk menata kembali susunan organisasi mereka agar fungsi manajemen dapat diterapkan secara maksimal dan terstruktur.

Beberapa anggota organisasi merasa bahwa pelatihan ini sangat dirasa manfaatnya terutama dalam pembenahan pengelolaan manajemen organisasi yang selama ini sering terjadi tumpang tindih dalam hal pengambilan keputusan. Sehingga dengan adanya pelatihan ini, anggota masyarakat menjadi lebih cerdas dalam mengambil keputusan. Kegiatan ini juga memberikan value added, serta meningkatkan kinerja bagi pengurus dan anggota organisasi. Dampak positif lainya adalah anggota organisasi menjadi lebih cerdas dalam menentukan tehnik atau pola kepemimpinan yang ideal yang dapat membawa perubahan positif bagi organisasi agar terus maju dan berkembang menjadi setara dengan kelurahan lainnya.

\section{Acknowledgements}

Ucapan terimakasih diberikan kepada Universitas Bumigora selaku pelindung dalam kegiatan ini, Ketua LPPM Universitas Bumigora beserta pengurus yang telah membantu menyelenggarakan kegiatan ini dan Pengurus Taman Batulayar serta semua peserta yang telah memberikan waktunya untuk kegiatan pelatihan ini. Semoga kegiatan pengabdian ini memberikan manfaat bagi kita semua. 


\section{Daftar Pustaka}

Dewi, P. (2019). Group discussion and ICTs in teaching and learning English in large classes. Inovish Journal, 4,2, p.20-32.

Effendy, O. U. (2003). IImu, teori dan filsafat komunikasi. Bandung: Citra Aditya Bakti.

Hasibuan, M. S. P. (2016). Manajemen Sumber Daya Manusia (Edisi Revi). PT. Bumi Aksara, Jakarta.

Kristiawan, M., Safitri, D., \& Lestari, R. (2017). Manajemen Pendidikan. Yogyakarta: Deepublish.

Marno., \& S. T. (2008). Manajemen dan Kepemimpinan Pendidikan Islam. Bandung: PT Refika Aditama.

Masruri, F. (2018). manajemen-organisasi-pengertian-manajemen-dan-organisasi. Retrieved from Kompasiana website: https://www.kompasiana.com/fazahpi/5a88473fcaf7db0ecd10b743/manajemen-organisasipengertian-manajemen-dan-organisasi?page=all\#section2

Rivai, V. (2013). Manajemen Pemimpin dan Kepemimpinan Dalam Organisasi. Rajawali Pers: Jakarta.

Syafaruddin, A. (2015). Manajemen Sumber Daya Manusia Strategi Keunggulan Kompetitif. Yogyakarta: BPFE. 


\section{ADMA}

Jurnal Pengabdian dan Pemberdayaan Masyarakat
Vol.1, No.1, June 2020, pp. 1-10

Doi: $x x x x x x x x$ 